\begin{tabular}{|c|c|c|c|c|c|c|}
\hline \multirow{4}{*}{ Impact Factor: } & ISRA (India) & $=3.117$ & SIS (USA) & $=0.912$ & ICV (Poland) & $=6.630$ \\
\hline & ISI (Dubai, UAF & $=0.829$ & РИНЦ (Russia) & $=0.156$ & PIF (India) & $=1.940$ \\
\hline & GIF (Australia) & $=0.564$ & ESJI (KZ) & $=5.015$ & IBI (India) & $=4.260$ \\
\hline & JIF & $=1500$ & & & & \\
\hline
\end{tabular}

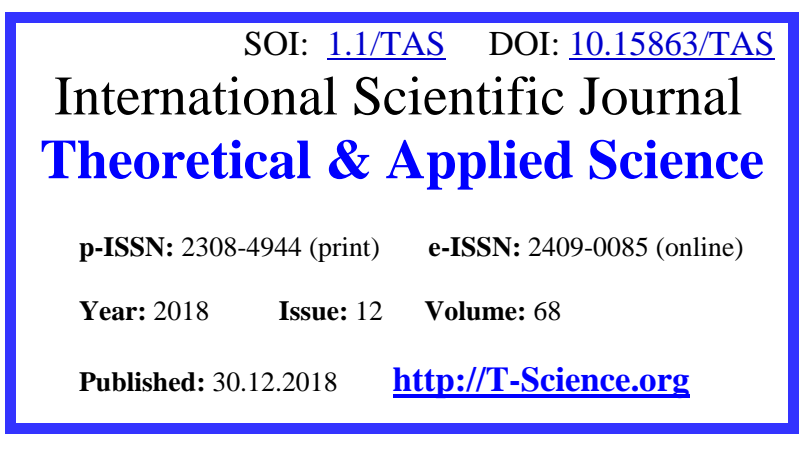

SECTION 31. Economic research, finance, innovation, risk management.
QR - Issue

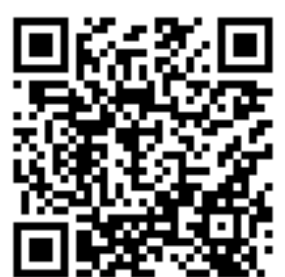

QR - Article

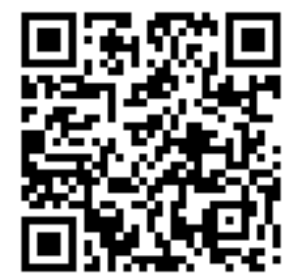

D.S. Ziyayeva

Tashkent state technical university, Tashkent city, Republic of Uzbekistan

\title{
DIRECTIONS OF IMPLEMENTATION OF FOREIGN EXPERIENCE CORPORATE MANAGEMENT IN COMMERCIAL BANKS
}

Abstract: The article analyzes the foreign experience of corporate governance, in particular, considered the features of corporate governance in the United States and Britain. Based on the study of foreign experience, the author suggested ways of introducing elements of corporate governance in commercial banks.

Key words: bank, corporate governance, foreign experience, market economy.

Language: English

Citation: Ziyayeva, D. S. (2018). Directions of implementation of foreign experience corporate management in commercial banks. ISJ Theoretical \& Applied Science, 12 (68), 347-353.

Soi: http://s-o-i.org/1.1/TAS-12-68-52 Doi: crossef https://dx.doi.org/10.15863/TAS.2018.12.68.52

\section{Introduction}

The widespread introduction of corporate governance, including the banking sector, is related to the fact that the global economic development is intensified by institutional integration of business entities at the beginning of the 21 st century. This is because first of all it is explained by the desire of banks to reduce the cost of production, distribution and sale of goods, to increase the revenues, to increase the profitability of the capital, and to strengthen their competitiveness in the national and international markets.

Recently, the problem of corporate governance in the Republic of Uzbekistan has attracted the attention of mass media and the public. This, first of all, provides for the protection of rights and interests of stockholders and other stakeholders. It is worth noting that many of the key factors in corporate governance are investors' decision to invest in our country in capital investment.

Problems of corporate governance in commercial banks of the Republic have started to develop in the early years of the 21 st century. Research on various aspects of this issue has been published in 2001, and this trend remains one of the most important and relevant issues at the moment. Before speaking about the essence and peculiarities of corporate governance in commercial banks, it is appropriate to describe its concept.

\section{Literature review}

Theoretical bases of corporate governance in commercial banks Gerashenko V.V., Djonatan Meysi, Morin Ohara, Diana Mak Noton, Jan Matuk, Zaharoz BC, Chris Barltrop, Klaus Baynke, Kiselev V., Lavrushin O., Matovnikov M. Yu., Olxova R.G., Rid E., Kotter R., Savinskiy Yu.P., Usoskin V.M. and other scientists' scientific findings.

In the transition to a market economy, some aspects of corporate governance were studied by M.Hamidulin, I.Butikov and others. Most of these things are basically curricular descriptions, in which the general theoretical aspects of corporate governance are highlighted.

However, comprehensive, scientific and theoretical and practical research on corporate governance issues has not been undertaken in commercial banks.

\section{Purpose of research}

Development of relevant recommendations and practical recommendations on improving the effectiveness of corporate governance practices in the context of deepening of the market economy and re-structuring international experience of corporate governance.

\section{Analysis and results}

Corporate governance is a complex of core activities and rules that are exercised by the General Meeting of Shareholders, the members of the 


\begin{tabular}{|c|c|c|c|c|c|c|}
\hline \multirow{4}{*}{ Impact Factor: } & ISRA (India) & $=3.117$ & SIS (USA) & $=0.912$ & ICV (Poland) & $=6.630$ \\
\hline & ISI (Dubai, UAI & $=0.829$ & РИНЦ (Russia) & $=0.156$ & PIF (India) & $=1.940$ \\
\hline & GIF (Australia) & $=0.564$ & ESJI (KZ) & $=5.015$ & IBI (India) & $=4.260$ \\
\hline & JIF & $=1.500$ & SJIF (Morocco) & $=5.667$ & & \\
\hline
\end{tabular}

Council and other executives in managing the activities of joint-stock companies;

$>$ Ensuring the effectiveness of joint-stock companies' activity, ownership and other interested parties (bank employees,

$>$ a system of relationships between bank managers and owners (shareholders) on issues of protecting the interests of creditors, partner banks;

$>$ all laws, regulations, regulations, measures and procedures to address the problems arising from the direct deterrence of corporate property from proprietors;

$>$ is a set of organizational, legal and economic measures that will unite the interests of key stakeholders in organizing effective bank management through them.

As a result of analyzes and studies, it was found out that in the developed foreign countries the following models of corporate governance are being used:

- unitary model - USA, UK, Australia;

- two-stage (stakeholder) model - Germany;

- Continental model;

- network model - Japan (keyretsu), Korea (chaebol).

Unitary Model System:

Unlike the executive directors, the Unity Board of Directors, which has more than one independent director, is a British Commonwealth Model (24\% $30 \%$ share-based, long-term, smaller, and controlling package, $70-80 \%$ shares, vice versa, with the time being released and easily available from one owner to another;

- The majority of stock capital is invested in invested in English-language traditions ("Protestant capitalism");

- shares held by non-physical entities are mainly concentrated in the hands of institutional investors;

- The bulk market is characterized by high efficiency and liquidity;

- Protecting monetary shareholder rights at a high level. In a two-step model, the management functions are clearly divided into two stages:

- Board of Directors (Board of Directors);

- executive board.

In the system of the Continental model, corporations, as well as joint-stock companies, may also have other legal entities such as various types of companies (full, limited liability companies), economic societies (limited liability companies), business associations (concerns, associations, holdings), production and consumer co-operatives is understood. The Anglo-Saxon model system also includes corporations that are not legal entities or entities that are not recognized as corporates in the Continental Model System (here it is about government agencies dealing with word-management activities). Thus, in the case of the continental model, corporations are generally considered as subjects of the private model, in the Anglo-Saxon model system they (England, USA) are not only private, but also the subject of the mass model.

All corporations, such as the United States, are divided into four groups: public, semi-public, commercial, non-profit. Popular corporations include government and local authorities. Semi-mass corporations are corporations, which account for the general needs of the population (eg gas, water, electricity). Religious organizations, corporations, such as corporations, schools, colleges, universities, corporations, etc. Corporations (entrepreneurial) corporations are corporations with a view to obtaining income, which are distinguished by the fact that they are economically powerful amongst the aforementioned corporations The political influence of such corporations is also significant medical involvement includes a complex system (combining with the modeling of a public modeling regulatory model) and is more detailed in relation to other types of corporations.

If the essence of the concept of commercial corporations originates, it is clear that the concept of corporations is clear and broader in Europe than in the UK and the US model.

Under the law, shirkats are not included in the UK as well as corporations that have the status of a legal entity in the United States. According to the general principles of the common model, the partnership is a combination of individuals and is not recognized as a legal entity. Commercial corporations are based only on equity capital, ie their corporation that reminds the state-owned companies in their continental model system.

In England and the United States, state-owned enterprises are relatively smaller than those of Europe, yet they are recognized as corporate entities in the Anglo-Saxon model. The european continental model is one of the most important signs of corporations, with regard to state-owned companies, that is, the combination of capital, the use of stateowned property and economic and organizational management of economic and organizational management as legal entities are not recognized as such corporations. Property relations arising among them are not related to the property conviction.

One of the major signs of the corporation is the existence of a pooled equity through the purchase of shares on a voluntary basis at the expense of founders or participants. The range of individuals and their share of their capital to organize the corporations' activities can be fixed at any time at the presence of corporations. As state enterprises do not have such criteria, the continental model is not recognized as corporations in the system. In the Continental model, there is relatively strong relationships between the members of the corporation. This is explained by the fact that each 


\begin{tabular}{|c|c|c|c|c|c|c|}
\hline \multirow{4}{*}{ Impact Factor: } & ISRA (India) & $=3.117$ & SIS (USA) & $=0.912$ & ICV (Poland) & $=6.630$ \\
\hline & ISI (Dubai, UAE & $=0.829$ & РИНЦ (Russia) & $=0.156$ & PIF (India) & $=1.940$ \\
\hline & GIF (Australia) & $=0.564$ & ESJI (KZ) & $=5.015$ & IBI (India) & $=4.260$ \\
\hline & JIF & $=1.500$ & SJIF (Morocco) & $=5.667$ & & \\
\hline
\end{tabular}

participant has an important role in the corporation through its distinctive feature of its activities that involves direct and indirect participation. However, there is a combination of participants (except in the United States) who are not indispensable for individual participation, even in joint-stock companies, which promotes the importance of the General Assembly of Shareholders. This approach allows the individual interests of the shareholders to correlate corporate interests, that is, the common interests of all members. Large corporations with relative strengths in the United States, where capital accumulation plays an important role, can only be effectively created if they use appropriate management technology. The opportunity to influence their shareholders on the business of the continental model shows that the legal status of the shareholders is their freedom and equality. The intrinsic corporate relationships with AngloAmerican corporations are where the legal status of shareholders is characterized by stockpiles and omissions of shareholders in managing corporations. Strangely enough, it should be noted that this is a positive situation and serves as a foundation for successful corporate governance, as managers of non-profit managers quickly and efficiently solve many issues and achieve profitability and profitability by expressing common and individual interests .

Whereas American and UK corporations are relatively free, the activities of European corporations are significantly regulated by the government. In the initial stages, European countries sought to regulate only external relations of corporations and their relationships with other legal entities (such as taxation, competition, consumer relationships, pensions and benefits to employees). Nowadays, the relationships within the corporation (such as the shareholder register, bookkeeping, conducting financial calculations through the bank) are also regulated by the state.

In the Anglo-Saxon model, the legal capacity of corporations was initially very special. The supreme legislative or executive authorities issued a permit for the existence of a particular type of activity. Today, many countries using this model have switched to the corporation to set up a common legal capacity that would enable the corporation to engage in any type of government-run business activity. The 1984 American Entrepreneurial Corporation Act, as well as the statutory US law, has been permitted to engage in activities that are well-known in the future with industry or business relationships, or have nothing to do with its core business. Therefore, no corporation is practically limited in its activities regardless of its type of business.

Therefore, the distribution of shares in these countries is as follows: $70-80 \%$ of the stock holdings are held for permanent owners; $20-30 \%$ of shares are offered for retail sale, and customers are considered as funds for temporary placement of funds;

- Large "wholesale" investors form the share capital,

the system of mutual ownership (strong dependence) of each other's shares is widely developed;

- Representation of the Company's employees at the Supervisory Board;

- far-reaching investors;

- The securities market is smaller and liquidity is low. Network (Japanese) model

The Japanese model does not resemble both the US model and the German model, but features some of the features of both models:

- Independent directors of the Board of Directors are responsible for this.

All members of the Council are senior managing bodies or former dictators;

- The share of equity investments is largely invested by major investors and the ownership of shares of one of the members of a single industry group is critical.

- The American system of corporate governance is directly related to the properties of the US property. In particular, there is no major investor in American corporations that can effectively influence other investors. The share capital of American corporations has largely been subdivided into smaller packages, with no individual or institutional investor registered in most U.S. registries, over one percent of total capital. As a result, no group of shareholders can nominate a member of the board of directors. The second important feature is that most of the shares that are not owned by individuals are concentrated in the hands of institutional investors pension funds and mutual funds. It's a great opportunity for investors to invest more than $50 \%$ in their hands, as more financial manager. and do not seek to participate in the board of directors, and usually avoid the responsibility for the ownership of companies that own large packages.

Shared capital stock makes it easier for shareholders to move from one owner to another. In May the shareholder can easily decide on the sale of its shares, but the sale of a large shareholder will usually result in changes in strategic plans and the loss of the offered value of the shares (one-time increase in the market offer). The high level of efficiency and liquidity of the American securities market makes it difficult for small investors to sell their packages quickly and technically. Accession, acquisition, acquisition and acquisition of a company are a common practice of the American stock market, which makes the stock market an effective tool for managing the managers' operations effectively and easily.

In contrast to the United States, the majority of Germany's equity capital is owned by other 


\begin{tabular}{|c|c|c|c|c|c|c|}
\hline \multirow{4}{*}{ Impact Factor: } & ISRA (India) & $=3.117$ & SIS (USA) & $=0.912$ & ICV (Poland) & $=6.630$ \\
\hline & ISI (Dubai, UAI & $=0.829$ & РИНЦ (Russia) & $=0.156$ & PIF (India) & $=1.940$ \\
\hline & GIF (Australia) & $=0.564$ & ESJI (KZ) & $=5.015$ & IBI (India) & $=4.260$ \\
\hline & JIF & $=1.500$ & SJIF (Morocco) & $=5.667$ & & \\
\hline
\end{tabular}

companies: more than half of Germany's gross share capital comprises a system of interoperability with ownership of one another's shares. Even though private investors form the second largest group of investors in Germany (they hold approximately $16 \%$ of German companies), many of their shares are certified by their respective holders, whose certificates are owned by their respective owners, whose majority of shares are owned by banks. For this reason, a large proportion of German companies' shares (more than 90\%) are traded by organizational investors, even if they are not shareholders.

The Goldman Sachs Joint Stock Company focuses on infor- mation technologies in the implementation of corporate governance. Particularly, in 2008, they managed to reduce the costs by $90 \%$ without waiting for the crisis, and as a result, it was reported that $1000 \%$ provided their clients and clients.

The Goldman Sachs financial institution focuses on maintaining asset trust and repayment of bank assets through asset management in asset management (based on bank assets' risk level). These issues were directly achieved through the corporate governance of the Bank's shareholders.

The Goldman Sachs Bank focuses on managing corporate governance in the context of crisis, focusing on asset allocation, risk management, and commitment.

Goldman Sachs achieved positive results in the context of the global financial crisis, taking into account the third-party partners involved in corporate governance, which effectively utilized their financial resources on close and economical basis with the "third partners".

Until recently, state-owned enterprises in Uzbekistan have absolute majority, and today their numbers have dropped significantly. Many enterprises were transformed into joint-stock companies. However, in most of the joint-stock companies, a significant part of the stock controlling block is owned by the state. While the share of stateowned enterprises in the Continental Europe is still small, it still exists. In Uzbekistan, state-owned enterprises can be employed in areas such as transport, communication, informatics, fuel and energy, which serve the whole population of the population (such as defense enterprises) or in areas that are only publicly funded (mining and oil refining, and industry).

\section{Introduction of the international experience of corporate governance in the National Bank system and its prospects}

It is well-known that one of the most important issues of commercial banks is the involvement of free funds in the economy and the effective allocation of these funds. Because of the intensification of market relations and further liberalization of the economy, the demand for financial resources is growing in commercial banks, and the need for long and short-term loans from banks is growing. Formation of these funds and their effective management remain one of the important issues. There is a positive impact on the "free distribution" between banks and the growth of free competition in attracting additional resources from the financial market.

It is known from the experience of the international banking practice and the short-lived market economy that the main resource base of commercial banks is their depository resources. Demand deposits in the structure of deposits are lowcost, but in terms of uncertainty. Term and savings deposits of banks are stable in terms of their duration, but are the source of expensive loans.

The following figure analyzes the structure and dynamics of deposit resources of commercial banks of the Republic of Uzbekistan.

According to the image data, the share of fixedterm deposits in the structure of deposits of commercial banks is the most important. This figure declined between 2008 and 2009 when the total amount of deposits was $79.5 \%$ as of 1 January 2008 . However, this source of deposits in commercial banks had a tendency to rise again on January 1, 2010.

The share of demand deposits (fixed-term deposits) in the structure of deposit funds of commercial banks testifies to the existence of contradictory situations in which they are vulnerable to deposit base and effective resource management. Specifically, there are problems with the lack of funds in the balance sheet, the lack of customer satisfaction, and the need to provide the requisite resources for the financing of projects.

The findings and findings of the study indicate that most commercial banks do not have a short-term and long-term strategic development policy in attracting resources. This is a reason for their strict implementation of the deposit policy in the country's financial market. As a result, some commercial banks are formed from relatively stable resources and their share remains high.

The problem of introduction of corporate governance in the formation of the commercial banks' resources is explained by the following:

- First of all, the practice of forming resources at the expense of time deposit funds of commercial banks is very weak.

Commercial banks have a strong need for sustainable resources as a short-term credit institution. The main part of this demand will be the liquidity of the banks, which will be financed through their deposits.

As we have already mentioned, the funds on demand deposits of banks are relatively unstable. 


\begin{tabular}{|c|c|c|c|c|c|c|}
\hline \multirow{4}{*}{ Impact Factor: } & ISRA (India) & $=3.117$ & SIS (USA) & $=0.912$ & ICV (Poland) & $=6.630$ \\
\hline & ISI (Dubai, UAE & $=0.829$ & РИНЦ (Russia) & $=0.156$ & PIF (India) & $=1.940$ \\
\hline & GIF (Australia) & $=0.564$ & ESJI (KZ) & $=\mathbf{5 . 0 1 5}$ & IBI (India) & $=4.260$ \\
\hline & JIF & $=1.500$ & SJIF (Morocco) & $=5.667$ & & \\
\hline
\end{tabular}

Banks can use these funds as credit resources in active operations. However, the use of these funds as a loan source has a significant adverse effect on their liquidity. Because the deposited deposit can be partially or entirely unexpectedly anticipated by the customer at the time of the request. Or, due to the financial disadvantage of the borrower, the loan can not be returned to the bank. In this case, the bank will suffer double economic damage. First of all, it can not satisfy the customer as a result of the inability to provide liquidity. Secondly, the loan will be deprived of the credit and credit interest expected from it. Hence, the deposition of long-term savings deposits into long-term asset operations is an unstable financial source, which may have a detrimental effect on banks' stability and their stability.

- Secondly, financial resources of commercial banks are formed from relative sources of funding or their capacity for active operations is limited.

The picture below shows the dynamics and dynamics of demand deposits in total deposits of commercial banks of the Republic of Uzbekistan. As you can see from Figure 2.2, the share of fixed-term deposits in total deposits of commercial banks has remained almost unchanged during 2008-2012 and still remains high. This reduces the liquidity level of banks. This was a problem of effective management of financial resources of commercial banks.

Thirdly, legal entities and individuals are not interested in the transfer of funds to banks' term and savings deposits.

Legal entities and individuals tend to invest money on long-term and savings deposits only if they are convinced that the Bank has been able to maintain, recover and replenish the funds deposited.

The level of inflation also plays an important role in depositing funds into fixed-term funds. If the level of inflation is considerably high, the economic interest of the depositors will be reduced. As a result, the tendency of bank transfer to the bank is reduced. Because the amount of income from these deposits will lose their value due to inflation.

Commercial banks do not have the resources they are exposed to at the expense of deposit funds in terms of their active operations. Because the total amount of deposit resources in the commercial banks is very low.

Thus, the practice of attracting credit resources from commercial banks' deposit operations is very weak, which is one of the major problems in managing bank resources.

When analyzing the structure of deposit funds of commercial banks, the share of fixed-term and savings deposits was insignificant. In our view, one of the main reasons for the decline in the share of time and savings deposits in commercial banks is the vulnerability of the population to the banking system. Poor vulnerability of the population to the banking system has a significant impact on the banks' attraction of deposits and creates the basis for the cash flows out of the bank.

It is noteworthy that in most (even in the developed) countries, a certain amount of money transactions between economic entities is carried out outside of the banking system. This is due to the existence of the economy.

In general, the share of the economy in the developed countries is $5-10 \%$ of GDP, while in the developing and the Commonwealth of Independent States - 25 to $60 \%$. It should be noted that when the share of the economy in the country is about $40-50$ percent of GDP, its effect is growing so that its effect is observed in practically all sectors of the society. Hence, the presence of these circumstances in the society has a negative impact on the strengthening of the population's confidence in the banking system, but also creates direct conditions for the outflow of funds.

In our opinion, it is necessary to take into account the following key factors in increasing the involvement of time deposits in deposit accounts of commercial banks and strengthening their confidence in the banking system.

Article 38 of the Law of the Republic of Uzbekistan "On Banks and Banking Activity" states that "Banks guarantee the confidentiality of operations, accounts and savings of their clients and representatives".

Failure to provide customers with full or partial cash flows will have a negative impact on the volume of cash payments to their banking system. By February 2003, due to the fact that the cashier's scheme was in effect in the banking system, it required the banks to stop cash in the third decade of each month. Despite the cancellation of the cashier's plan since February 2003, satisfaction of customers' cash needs in the banking practice has not yielded any positive effect.

It should be noted that the National Bank of the Republic of Uzbekistan (TIF) accounts for $30.5 \%$ of the total deposits of commercial banks formed as of January 1, 2007. Hence, the National Bank of TIF is the only major bank in Uzbekistan to attract deposits among commercial banks.

Despite the fact that the deposit base of the National Bank of TIF is the only leader in total deposits of commercial banks of the republic, it is clear that the share of long-term savings deposits is relatively stable. The same can be said about Asakabank.

It is worth noting that almost all of the analyzed commercial banks remain in the form of a resource formation through the circulation of savings deposits, while the source of the commercial banks' resources is recognized as a sustainable financial resource.

One of the main benchmarks for managing commercial banks' resources in international 


\begin{tabular}{|c|c|c|c|c|c|c|}
\hline \multirow{4}{*}{ Impact Factor: } & ISRA (India) & $=3.117$ & SIS (USA) & $=0.912$ & ICV (Poland) & $=6.630$ \\
\hline & ISI (Dubai, UAI & $=0.829$ & РИНЦ (Russia) & $=0.156$ & PIF (India) & $=1.940$ \\
\hline & GIF (Australia) & $=0.564$ & ESJI (KZ) & $=5.015$ & IBI (India) & $=4.260$ \\
\hline & JIF & $=1.500$ & SJIF (Morocco) & $=5.667$ & & \\
\hline
\end{tabular}

banking practice is their share in the total social output of the country.

If we compare commercial banks with the coefficient of total investment to GDP, we will see that this level is much lower.

However, it is possible to raise this coefficient by reducing the volume of off-bank turnover, but the lack of confidence in the banking system does not give an opportunity to increase the effectiveness of the work done.

At the same time, it should be noted that the deposit market concentration in large banks of the country remains high. As a result, the banks' monopoly level affects the financial stability of medium and small banks.

\section{Ways to Use Positive Aspects of International Corporate Governance Experience}

Based on the research and researches in the study, we have witnessed the international experience of coordinating management in commercial banks. One of the key players in this regard is the effective system of corporate governance in a modern competitive bank, in accordance with the Basel Committee's documents, which will be reflected in the following main principles:

- The existence of a system of corporate culture, which has been strengthened in compliance with the code of conduct and other ethical standards, as well as a system that promotes these principles in practice;

- The existence of a clearly defined development strategy, the results of the work of all banks and individuals are assessed accordingly;

- Rights (including the hierarchy of certain rights in the decision-making sphere) and the precise distribution of responsibilities;

- The existence of a mechanism of effective cooperation between the Board of Directors, top managers and auditors;

- availability of a reliable internal control system (including effectiveness of this system by internal audit and external auditor) and risk management services (regardless of business lines and business units), as well as other elements of "restraint and balance" system;

- Continuous risk monitoring in certain sectors of the banking business, where potential conflicts of interest are likely to occur (first of all, those areas are interconnected with borrowers - affiliated and dependent individuals, major shareholders and senior managers, and secondly, leading traders in the stock market);

- availability of incentives for managers and other employees to increase their financial and service stuctures;

- availability of the required transparency of the information flow systems that provide internal needs of the organization and the external counterparts.

It is crucial for the banking business to operate on the principle of "restraint and balance" of corporate governance structures. The system of mutual restrictions includes four levels of control: a) Board of Directors; b) specially authorized persons not involved in day-to-day operations management; c) subdivisions of the bank which are directly responsible for various activities; g) risk management and internal audit services, independent from the business units and business units of the bank.

Under the Basel Committee on Banking Supervision, there are at least four members of the Board of Directors: audit, reward, assignment and risk management committees. Let's see how this procedure is being implemented in ten leading banks in the United States and the EU.

\section{Conclusion and recommendations}

Given the importance of a comprehensive approach to the competence and integrity of shareholders in banks, I have developed a number of specific proposals aimed at improving the efficiency of corporate governance at enterprises in Uzbekistan:

1. It is recommended to introduce the multidisciplinary and multi-disciplinary system based on the latest educational technologies in the field of personnel recruiting, retraining and advanced training as an effective tool for improving the professionalism of the staff of joint-stock banks.

2. Intensive training of stockholders must include: computer technology for managerial analysis and decision making; independent work with scientific literature and execution of personal plan tasks;

use of distribution media; Testing the knowledge assessment module; studying new experiences in places; independent essays and research; educational system used in video equipment; computers and other modern teaching aids.

3. In the process of professional development of the staff of joint-stock banks it is necessary to achieve a new scientific methodological level,

so that they have the opportunity to acquire the latest knowledge in the field of market economy and to build up modern financial management skills. 


\begin{tabular}{llllll} 
& ISRA (India) $=\mathbf{3 . 1 1 7}$ & SIS (USA) $=\mathbf{0 . 9 1 2}$ & ICV (Poland) & $\mathbf{= 6 . 6 3 0}$ \\
Impact Factor: & ISI (Dubai, UAE) $=\mathbf{0 . 8 2 9}$ & PUHL (Russia) $=\mathbf{0 . 1 5 6}$ & PIF (India) & $=\mathbf{1 . 9 4 0}$ \\
& GIF (Australia) $=\mathbf{0 . 5 6 4}$ & ESJI (KZ) & $\mathbf{5 . 0 1 5}$ & IBI (India) & $=\mathbf{4 . 2 6 0}$ \\
& JIF & $\mathbf{1 . 5 0 0}$ & SJIF (Morocco) $=\mathbf{5 . 6 6 7}$ & & \\
\hline
\end{tabular}

\section{References:}

1. Reed, E., et al. (1991). Commercial banks. Per. with ang ed. Usoskin V.M. (Eds). (p.135). M.: Cosmopolis.

2. (2007). Center for Economic Research. The impact of remittances on the economy of Uzbekistan. (p.42). Tashkent.

3. (1980). Preventing Bank crises. (p.456). Lessons From Resent Global Bank Failures.

4. Chris, J. (1994). Barltrop and Diana MacNoton. Interpretation of financial statements. Tom P. (p.231). The World Bank. Washington, D.S..

5. McConell, C. R., \& Bru, S. L. (1992). Economics. Volume I. Trans. from ang. (p.399). M: Republic.

6. Matuc, J. (1994). Financial systems of France and other countries. I, II volume. Per. from ang. $\mathrm{M}$.: Finstatinform.
7. Dadaaboev, X. (2002). The new phase of the Basel Capital Accord. Bozor, pool va loan. Toshkent, №8, 15-17.

8. Bobylev, M. P. (2002). Corporate regulation of documentation support of management in the bank. Money and credit.

9. Muradov, N. (n.d.). Improving corporate governance.

10. Murychev, A. V. (2003). On ways to strengthen the resource base of Russian commercial banks. Money and credit, Moscow, №11, 48-52.

11. Brunner, A. D., Decressin, J., Hardy, Daniel, C. L., \& Beata, K. (2004, Jjune 21). Germany's Three-Pillar Banking System. Cross-Country Perspectives in Europe". International Monetary Fund. ISBN 1-58906-348-1. ISSN 0251-6365. 